\section{Effect of Indoor Exposure on the Cold Hardiness and Physiology of Containerized Christmas Trees}

\author{
N.J. Gooch ${ }^{1,3}$, Pascal Nzokou ${ }^{1,4,6}$, and Bert M. Cregg ${ }^{2,5}$
}

ADDITIONAL INDEX wORDs. artificial freeze test, bud mortality, chlorophyll fluorescence, deacclimation, dormancy, survivability

Summary. Containerized conifers are increasingly marketed and used as live Christmas trees worldwide. However, prolonged exposure to indoor conditions may reduce cold hardiness. We examined physiological and morphological changes of three species black hills spruce (Picea glauca), balsam fir (Abies balsamea), and douglas fir (Pseudotsuga menziesii var. glauca) subjected to in-home conditions for 10 and 20 days. Shoot cuttings were subjected to artificial freeze testing (AFT) and the physiological and morphological changes were evaluated by chlorophyll fluorescence, bud mortality, and needle damage. After 7 days indoors, bud temperature at $50 \%$ lethality $\left(\mathrm{LT}_{50}\right)$ was $-24.5^{\circ} \mathrm{C}$ for douglas fir, $-23.5^{\circ} \mathrm{C}$ for black hills spruce, and $-22.5{ }^{\circ} \mathrm{C}$ for balsam fir. After 20 days indoors, bud $\mathrm{LT}_{\mathbf{5 0}}$ increased to $-18^{\circ} \mathrm{C}$ for black hills spruce and balsam fir, and $-21^{\circ} \mathrm{C}$ for douglas fir. The effect of the indoors exposure on needle damage was very limited for black hills spruce and balsam fir; however, severe needle damage was apparent on douglas fir even at just 3 days of indoor exposure $\left(\mathrm{LT}_{50}=-21^{\circ} \mathrm{C}\right)$. This negative impact worsened with indoor exposure time with $\mathrm{LT}_{50}$ for after 20 days of indoor exposure at $-7^{\circ} \mathrm{C}$. Chlorophyll fluorescence values followed a similar trend with needle damage with black hills spruce and balsam fir showing no difference, while douglas fir values were significantly affected. These results confirm the hypothesis that live trees kept indoors for extended periods progressively deharden and become very sensitive to cold damage when moved outdoors following the indoor exposure. However, whole plant survival after transplantation in the field did not corroborate results obtained from the AFT. Further studies are needed to investigate the potential causes of the high transplantation mortality following the display treatments.

$\mathrm{R}$ ecently, there has been an increasing interest in using live containerized conifers as an alternative to traditional cut Christmas trees. Live trees are used indoors for the holiday season and can be planted in the home landscape after the holiday (Bates, 2007). They exhibit better needle retention when displayed, and disposal is not an issue because these trees can be planted. In addition, live Christmas trees appeal to consumers concerned about the cutting of living trees for the holiday. However, using containerized trees presents some serious physiological challenges related to dormancy. In colder climates, evergreen species

\footnotetext{
${ }^{1}$ Department of Forestry, Michigan State University, 126 Natural Resources Building, East Lansing, MI 48824

${ }^{2}$ Department of Horticulture, Michigan State University. A222 Plant and Soil Sciences Building, East Lansing, MI 48824-1325

${ }^{3}$ Graduate Research Assistant.

${ }^{4}$ Assistant Professor.

${ }^{5}$ Associate Professor.

${ }^{6}$ Corresponding author. E-mail: nzokoupa@msu.edu.
}

stop photosynthesis in late summer as they prepare for dormancy (Bannister and Neuner 2001; Dungey, 2007). During this time, tissue and buds begin to harden, allowing the tree to tolerate cold winter temperatures without damage. Bringing trees into a heated house may interrupt dormancy and result in the rapid loss of hardiness (Bigras et al., 2001; Glerum, 1985). If the trees are subsequently exposed to temperatures below their hardiness limit, damage may be substantial, even resulting in mortality (Bigras et al., 2001; Glerum, 1985). For these reasons, special care recommendations must be made available to consumers for proper handling and improvement of postholiday tree survival.
The literature on the care of a living Christmas tree is often vague and inconsistent, and is not based on scientific evidence. Most guidelines recommend allowing the trees to acclimate in an unheated garage before introducing them into a household (Haworth, 1998; Russ et al., 1999; Wray, 2005). The recommended time that the trees can spend indoors is highly variable, ranging from $3 \mathrm{~d}$ (Nix, 2006a), 5 to $7 \mathrm{~d}$ (Wray, 2005), 7 to $10 \mathrm{~d}$ (Nix, 2006b; Russ et al., 1999) and up to 2 weeks (Haworth, 1998). Recommendations to keep trees well watered are common, and it is recognized that the size and number of lights used for decoration can also affect dormancy due to radiant heat (Haworth, 1998; Russ et al., 1999; Wray, 2005). The postholiday handling of trees is another area of disagreement. Some reports recommend progressive reacclimation in an enclosed porch, then transfer to an unheated garage, and finally outside (Hoogasian, 1990), while others propose site preparation before the holiday and immediate planting following the time indoors (Wray, 2005).

Time spent indoors and its effect on dormancy is crucial, yet unknown. It is necessary to investigate the physiological and morphological changes of trees exposed to indoor conditions to determine the optimal time on display for tree survival and quality. Our goal was to investigate these changes in trees exposed to indoor conditions. This study will help in developing guidelines for handling containerized live Christmas trees.

\section{Materials and methods}

Tree species. Three species, black hills spruce, balsam fir, and douglas fir were included in this study. Fifteen trees of each species measuring 2 to $3 \mathrm{ft}$ in height were hand-dug from the Tree Research Center (TRC) on the campus of Michigan State University (MSU) at

\begin{tabular}{llll}
\hline $\begin{array}{l}\text { Units } \\
\begin{array}{l}\text { To convert U.S. to SI, } \\
\text { multiply by }\end{array}\end{array}$ & U.S. unit & SI unit & $\begin{array}{l}\text { To convert SI to U.S., } \\
\text { multiply by }\end{array}$ \\
\hline 0.3048 & $\mathrm{ft}$ & $\mathrm{m}$ & 3.2808 \\
3.7854 & $\mathrm{gal}$ & $\mathrm{L}$ & 0.2642 \\
2.54 & inch $(\mathrm{es})$ & $\mathrm{cm}$ & 0.3937 \\
$\left({ }^{\circ} \mathrm{F}-32\right) \div 1.8$ & ${ }^{\circ} \mathrm{F}$ & ${ }^{\circ} \mathrm{C}$ & $\left(1.8 \times{ }^{\circ} \mathrm{C}\right)+32$
\end{tabular}


East Lansing in Fall 2006. The trees were transplanted into 3 -gal pots (balsam fir and black hills spruce) and 5-gal pots (douglas fir) using a light medium of ground pine bark $(85 \%)$ and peatmoss (15\%) mixture. The medium was amended with sulfur to achieve a target $\mathrm{pH}$ of 5.5 .

The potted trees were watered to compact the soil and to ensure good root-to-soil contact by eliminating open air space. All trees were left outdoors at the MSU Horticulture Teaching and Research Center (HTRC) and were watered regularly until conditioning and testing began on 4 Jan. 2007. The HRTC is also the site of a Michigan Agricultural Weather Network (MAWN). Weather data from the station for the experimental time frame was downloaded and analyzed to assess the condition of the trees before the indoors conditioning (Fig. 1).

Conditioning AND Testing. All trees were transported in a heated room for indoors conditioning and testing. Trees were assigned at random to three indoor display durations: 0 (control or no indoor display), 10, or $20 \mathrm{~d}$. All trees were placed in a heated and lighted room, simulating conditions that a containerized tree would be exposed to in any standard household. Trees were watered two or three times per week, and thermocouples connected to data loggers were used to measure soil and air temperatures in each treatment. The maximum and minimum room temperatures as well as the root ball temperature conditions during the indoor and post-treatment conditioning are presented in Fig. 2.

Cuttings were taken from each tree on days $0,3,7,14$, and 20 for the cold hardiness study. On each day, 11 cuttings $\approx 2$ to 3 inches in length were taken from each tree. The cuttings were divided into one control and 10 temperature treatments for the freeze testing. After the initial cuttings were taken, the control trees were placed in an unheated barn for cold storage. The 10- and 20-d treatment trees were moved to the same barn at the end of the indoor period.

Artificial freeze test (AFT). Each cutting was assigned to a different exposure temperature of $-3,-6$, $-9,-12,-15,-18,-21,-24,-27$, and $-30{ }^{\circ} \mathrm{C}$. The cuttings were bundled according to temperature treatment,

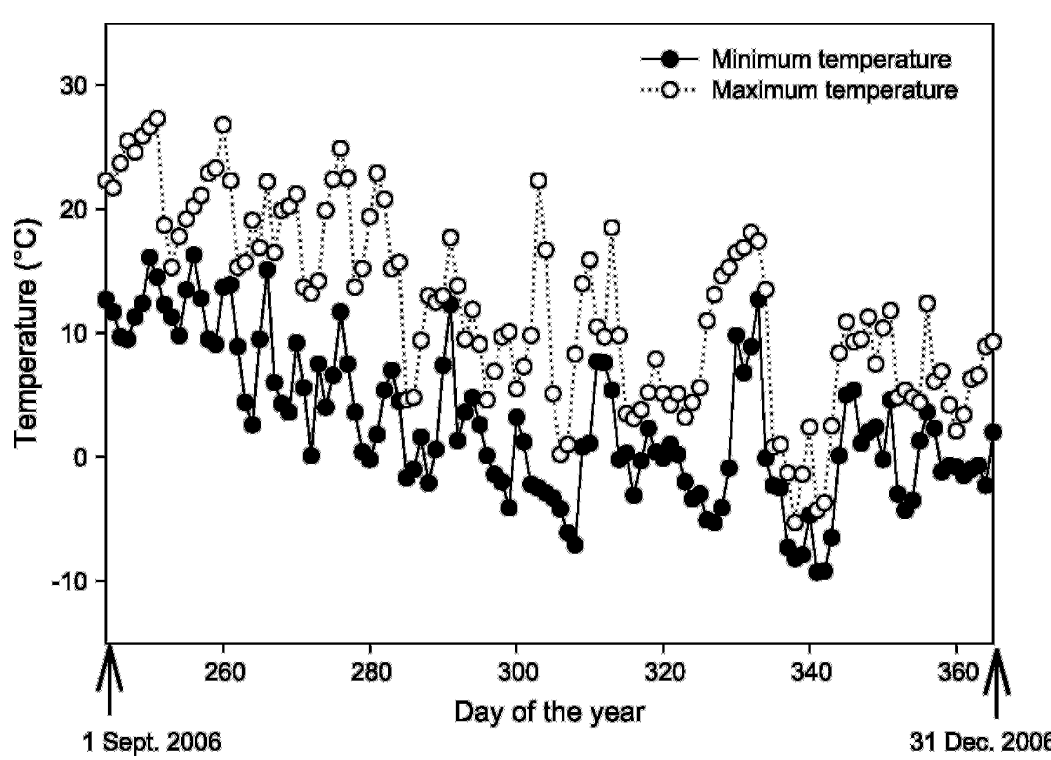

Fig. 1. Maximum and minimum air temperatures measured at the Michigan State University Horticultural Teaching and Research Center in East Lansing from 1 Sept. to Dec. 2006; $\left(1.8 \times{ }^{\circ} \mathrm{C}\right)+32={ }^{\circ} \mathrm{F}$.

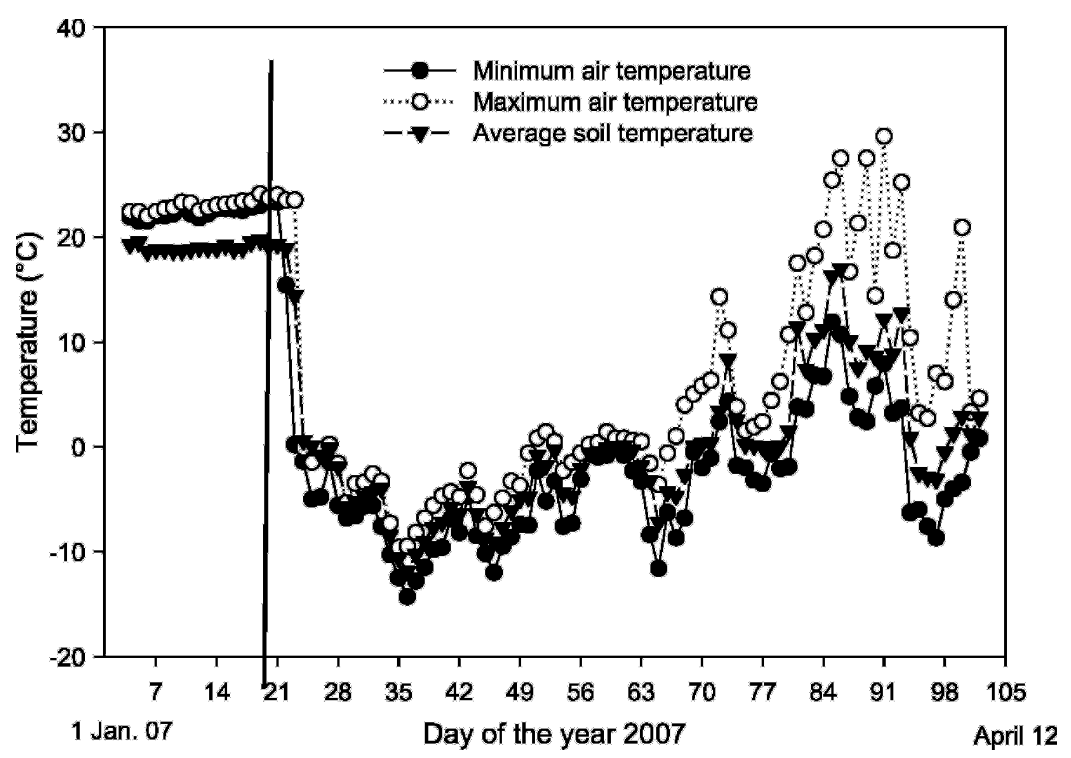

Fig. 2. Maximum and minimum ambient temperatures and average soil temperature measured with thermocouples during treatment. The vertical line represents the time at which the last trees were moved from indoors display into cold storage; $\left(1.8 \times{ }^{\circ} \mathrm{C}\right)+32={ }^{\circ} \mathrm{F}$.

wrapped in dampened gauze, and then covered in aluminum foil with a thermocouple inserted in the bundle to monitor the core temperature. The bundles were placed in a refrigerator at $4.5{ }^{\circ} \mathrm{C}$ for $24 \mathrm{~h}$ to allow acclimation before the AFT. The untreated controls remained in the refrigerator for the duration of the freeze test. The following day the test bundles were transferred to a programmable freezer (model 40-12A;
ScienTemp, Adrian, MI) equipped with CALgrafix programming software (Advanced Industrial Systems, Harrods Creek, KY). The temperature program used quickly brought the temperature to $0^{\circ} \mathrm{C}$, holding it there for $12 \mathrm{~h}$. The program then decreased the freezer's temperature at a rate of $3{ }^{\circ} \mathrm{C}$ per hour. Bundles were removed when the core temperature of the bundle monitored from inserted thermocouples reached the 
desired treatment temperature. The AFT as described above was repeated on cuttings collected after $3,7,10$, 14 , and $20 \mathrm{~d}$ of indoor display.

Postfreeze test evaluation. Following the freeze test, the bundles were returned to the refrigerator for $24 \mathrm{~h}$ and were then placed into an incubation chamber at room temperature for a period of 1 week to thaw and to allow damage to become visible (Glerum, 1985; Ritchie, 1984). Visual evaluations were made on the buds and the needles of each cutting. To evaluate bud damage, four buds were selected randomly from the cuttings and were removed. These buds were cut in half lengthwise to expose the bud center to assess mortality. Needle damage was assessed based on the presence of brown, necrotic, or dead needle tissues. Visual ratings were given on a scale of 0,1 , and 2 corresponding to no damage, some damage, and complete damage, respectively, and the percentage of damage was calculated as the proportion of needles with some or complete damage. The $\mathrm{LT}_{50}$ was determined graphically using a pairwise plot of the exposure temperature and the percentage of bud mortality or needle damage for each species.

Chlorophyll fluorescence was measured on each cutting using a portable plant efficiency analyzer (model Handy PEA; Hansatech Instruments, Kings Lynn, UK). Randomly selected needles were removed from each cutting, placed into a clip, and dark acclimated for a period of $15 \mathrm{~min}$, allowing all electron acceptors to fully oxidize and be available to receive light energy. Clips were then placed under the plant efficiency analyzer and the variable-tomaximum fluorescence ratio $(\mathrm{Fv} / \mathrm{Fm})$ was recorded.

Field survival. Following the indoor treatments, trees were moved to an unheated barn (cold storage) for the remainder of winter and were planted on 30 Mar. 2007. The barn had a few transparent roofing panels allowing some daylight into the structure during the day. The planting site was a freshly tilled field at the TRC. The soil at the planting location is classified as Spinks loamy sand, and is characterized as well drained with low available water capacity; fair for cropland, but good for pasture and woodland.
Soil moisture and rainfall were sufficient during and after the time of planting, precluding irrigation. Tree quality was assessed visually monthly based on the overall appearance of the whole tree. Visual appearance ratings, ranging from 1 to 5 (dead to excellent), was given to planted trees on a monthly basis, and the final evaluation and survival was recorded 3 months after transplanting.

Bud mortality and needle damage data were log transformed for statistical analysis. No transformation was needed for chlorophyll fluorescence data. Statistical analysis was one-way analysis of variance (ANOVA) using PROC GLM in SAS (version 9.1; SAS Institute, Cary, $\mathrm{NC}$ ) to test the effect of temperature treatments on bud mortality and needle damage. The ANOVA procedure was done for each temperature and species combination. Treatments were separated using Fisher's least significant difference (LSD) procedure $(\alpha=0.05)$.

\section{Results and discussion}

Evaluation OF PREDigging DORMANCY. In conifers, dormancy of seedlings consists of several stages (Cleary et al., 1978). During the first stage, plants become increasingly responsive to temperatures near or below freezing, which initiate a second stage of frost hardening (Glerum, 1985 ). Temperatures in Fall and Winter 2006 recorded from the MAWN station located at the MSU HTRC (1 mile from the TRC) were monitored (Fig. 1). Temperatures for 2006 were relatively mild, with daytime highs well above freezing and nighttime lows remaining near or above freezing much of the time. Temperature lows before the digging on 23 Oct. 2006 were generally above freezing. However, from the end of October and throughout the outdoor conditioning, temperature lows were generally around and below freezing, providing additional chilling hours for trees. Based on these weather data and considering the total budbreak observed on control trees after the test, it can be concluded that these containerized trees completed their dormancy process and accumulated enough chilling for their normal physiological cycle.
Bud COLD HARDiness. Cold hardiness evaluated by bud damage decreased in all species with indoor exposure time (Table 1). At the start of indoor display, buds of all species were hardy to -26 to $-28{ }^{\circ} \mathrm{C}$. The initial cuttings taken on day 0 for freeze testing gives an idea of the cold hardiness of the trees when they were brought in for the testing. Little damage was noticed until temperatures reached $-27^{\circ} \mathrm{C}$, and the lowest temperature of $-30{ }^{\circ} \mathrm{C}$ was required to cause $100 \%$ bud mortality in all species. Based on these observations, we concluded that buds tested were cold hardy and capable of withstanding temperatures colder than average January temperatures in the Lansing, $\mathrm{MI}$, area $\left(-8^{\circ} \mathrm{C}\right)$. After $3 \mathrm{~d}$ indoors, the three species showed various decreases in cold hardiness, with balsam fir having $100 \%$ bud mortality at $-27{ }^{\circ} \mathrm{C}$, while black hills spruce and douglas fir had $80 \%$ and $90 \%$ mortality. The $\mathrm{LT}_{50}$ after $3 \mathrm{~d}$ of indoor exposure was $-24.5^{\circ} \mathrm{C}$ for black hills spruce and $-25^{\circ} \mathrm{C}$ for balsam fir and douglas fir. The $\mathrm{LT}_{50}$ for the $7 \mathrm{~d}$ buds indicated that cold hardiness decreased to $-23.5^{\circ} \mathrm{C}$ for black hills spruce, $-22.5{ }^{\circ} \mathrm{C}$ for balsam fir, and $-24.5{ }^{\circ} \mathrm{C}$ for douglas fir. Day 14 and day 20 data followed a similar trend, with the $\mathrm{LT}_{50}$ increasing as time spent indoors increased. Trees exposed to $20 \mathrm{~d}$ indoor exposure had 10,9, and $5.5^{\circ} \mathrm{C}$ loss in hardiness for black hills spruce, balsam fir, and douglas fir, respectively (Table 1 ).

Needle morphology. Needle damage generally increased with indoor exposure time, but the overall effect was not significant for black hills spruce and balsam fir except for $20 \mathrm{~d}$ of indoor treatment and exposure at lowest temperatures of -24 to $-30{ }^{\circ} \mathrm{C}$ (Table 2 ). Douglas fir was the only species to show severe needle damage for all exposure times and test temperatures. The $\mathrm{LT}_{50}$ for douglas fir at day 0 was $-23{ }^{\circ} \mathrm{C}$; however, that value increased to $-7{ }^{\circ} \mathrm{C}$ by the end of the 20 -d treatment, representing a $16{ }^{\circ} \mathrm{C}$ loss in hardiness. At the conclusion of testing, douglas fir displayed the most needle damage, with damage at temperatures as high as $-3{ }^{\circ} \mathrm{C}$. The $20-\mathrm{d}$ treatment for black hills spruce did show some damage at $-15{ }^{\circ} \mathrm{C}$ with a $\mathrm{LT}_{50}$ of $-22{ }^{\circ} \mathrm{C}$, and balsam fir needles had no significant damage for all 
Table 1. Bud mortality and $50 \%$ lethality $\left(\mathrm{LT}_{50}\right)$ following the artificial freeze test at decreasing temperatures as related to the length of indoor exposure for black hills spruce, balsam fir, and douglas fir.

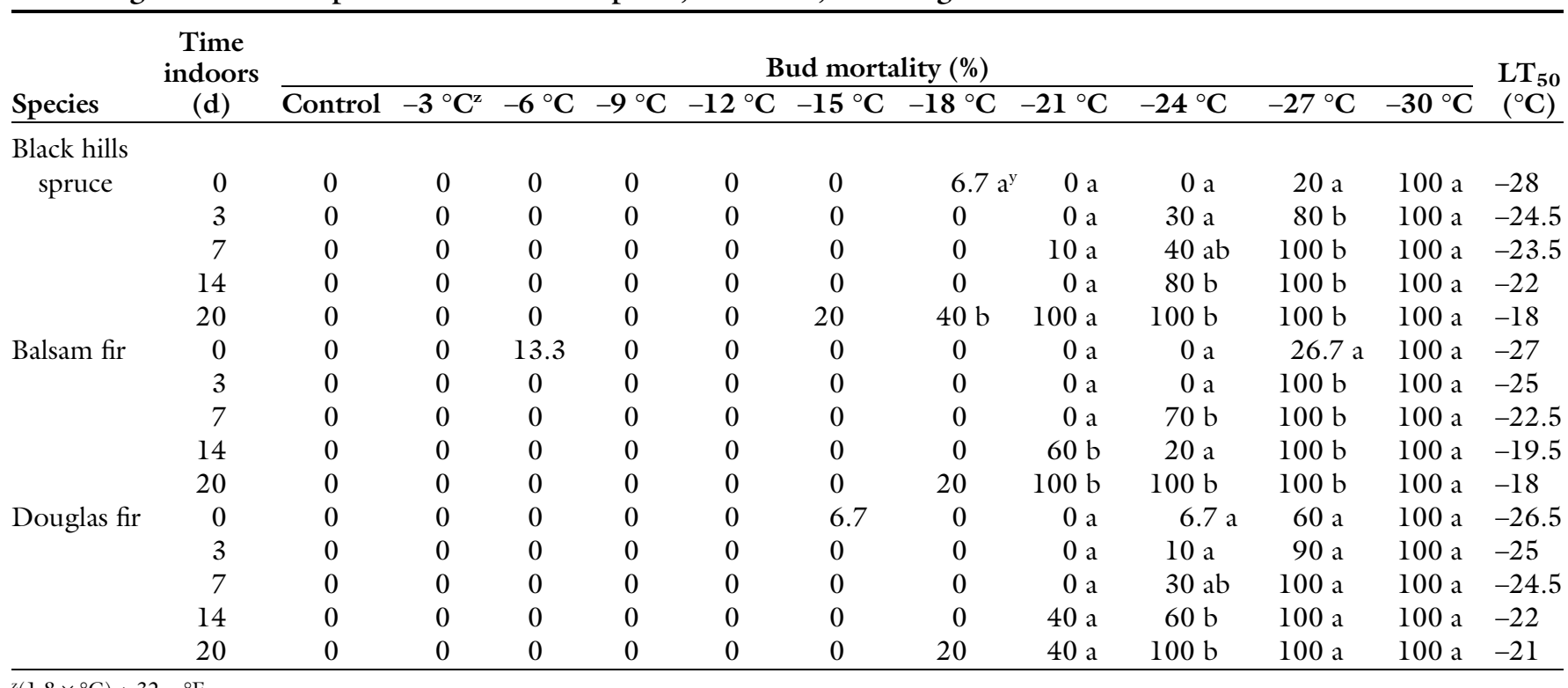

${ }^{\mathrm{z}}\left(1.8 \times{ }^{\circ} \mathrm{C}\right)+32={ }^{\circ} \mathrm{F}$

${ }^{y}$ Means followed by the same letter within a species and freeze test temperature (before artificial freeze test and after artificial freeze test) are not statistically different at $\alpha=0.05$. SAS PROC GLM (SAS Institute, Cary, NC) analysis showed that the differences between treatments were not due to chance. SAS least significant difference procedure was used to evaluate the significance of differences between the various indoor treatments for each freezing temperature.

Table 2. Needle damage and $\mathbf{5 0 \%}$ lethality $\left(\mathrm{LT}_{\mathbf{5 0}}\right)$ following the artificial freeze test at decreasing temperatures as related to the length of indoor exposure for black hills spruce, balsam fir, and douglas fir.

\begin{tabular}{|c|c|c|c|c|c|c|c|c|c|c|c|c|c|}
\hline \multirow[b]{2}{*}{ Species } & \multirow{2}{*}{$\begin{array}{c}\text { Time } \\
\text { indoors } \\
\text { (d) }\end{array}$} & \multicolumn{11}{|c|}{ Needle damage (\%) } & \multirow{2}{*}{$\begin{array}{l}\mathbf{L T}_{\mathbf{5 0}} \\
\left({ }^{\circ} \mathbf{C}\right)\end{array}$} \\
\hline & & Control & $-3^{\circ} \mathbf{C}^{\mathrm{z}}$ & $-6^{\circ} \mathrm{C}$ & $-9^{\circ} \mathrm{C}$ & $-12{ }^{\circ} \mathrm{C}$ & $-15^{\circ} \mathrm{C}$ & $-18^{\circ} \mathrm{C}$ & $-21^{\circ} \mathrm{C}$ & $-24^{\circ} \mathrm{C}$ & $-27^{\circ} \mathrm{C}$ & $-30{ }^{\circ} \mathrm{C}$ & \\
\hline & 3 & 0 & 0 & 0 & 0 & 0 & 10 & $0 \mathrm{a}$ & $0 \mathrm{a}$ & $10 \mathrm{a}$ & $0 \mathrm{a}$ & $20 \mathrm{a}$ & NA \\
\hline & 7 & 0 & 0 & 0 & 0 & 0 & 0 & $0 \mathrm{a}$ & $0 \mathrm{a}$ & $0 \mathrm{a}$ & $0 \mathrm{a}$ & $20 \mathrm{a}$ & NA \\
\hline \multirow[t]{5}{*}{ Balsam fir } & 0 & 0 & 6.7 & 6.7 & 6.7 & 0 & 0 & $0 \mathrm{a}$ & $0 \mathrm{a}$ & $0 \mathrm{a}$ & $13.3 \mathrm{a}$ & $6.7 \mathrm{a}$ & $\mathrm{NA}$ \\
\hline & 3 & 0 & 0 & 0 & 0 & 0 & 0 & $0 \mathrm{a}$ & $0 \mathrm{a}$ & $0 \mathrm{a}$ & $0 \mathrm{a}$ & $10 \mathrm{a}$ & $\mathrm{NA}$ \\
\hline & 7 & 0 & 0 & 0 & 0 & 0 & 0 & $10 \mathrm{a}$ & $0 \mathrm{a}$ & $0 \mathrm{a}$ & $10 \mathrm{a}$ & $0 \mathrm{a}$ & NA \\
\hline & 14 & 0 & 0 & 0 & 0 & 0 & 0 & $0 \mathrm{a}$ & $0 \mathrm{a}$ & $0 \mathrm{a}$ & $0 \mathrm{a}$ & $0 \mathrm{a}$ & $\mathrm{NA}$ \\
\hline & 20 & 0 & 0 & 0 & 0 & 0 & 20 & $0 \mathrm{a}$ & $0 \mathrm{a}$ & $0 \mathrm{a}$ & $0 \mathrm{a}$ & $0 \mathrm{a}$ & $\mathrm{NA}$ \\
\hline Douglas fir & 20 & 0 & 40 & 40 & 60 & 100 & 100 & $100 \mathrm{a}$ & $100 \mathrm{~b}$ & $100 \mathrm{ab}$ & $100 \mathrm{~b}$ & $100 \mathrm{a}$ & -7 \\
\hline
\end{tabular}

${ }^{\mathrm{z}}\left(1.8 \times{ }^{\circ} \mathrm{C}\right)+32={ }^{\circ} \mathrm{F}$.

${ }^{y}$ Means followed by the same letter within a species and freeze test temperature (before artificial freeze test and after artificial freeze test) are not statistically different at $\alpha=0.05$. SAS PROC GLM (SAS Institute, Cary, NC) analysis showed that the differences between treatments were not due to chance. SAS least significant difference procedure was used to evaluate the significance of differences between the various indoor treatments for each freezing temperature.

AFT temperatures tested. In this study, there was no clear relationship between needle damage and loss of dormancy for black hills spruce and balsam fir. However, they also indicate that based on needle damage, live douglas fir trees used indoors for 10 or $20 \mathrm{~d}$ and moved to outdoor conditions with winter temperatures as high as -3 to $-9{ }^{\circ} \mathrm{C}(20 \mathrm{~d})$ and -12 to $-18{ }^{\circ} \mathrm{C}(14 \mathrm{~d})$ would likely have severe injuries that compromised their survival.

Chlorophyll fluorescence. One of the first indices of a plant under stress is decrease activity of photosystem II (Schansker and van Rensen, 1999). This decrease affects the production of chlorophyll and can be measured by chlorophyll fluorescence. Decreases in $\mathrm{Fv} / \mathrm{Fm}$ values indicate stress. Black hills spruce and balsam fir had fairly consistent $\mathrm{Fv} / \mathrm{Fm}$ values throughout the range of exposure times and AFT temperatures (0.6-0.85) (Fig. 3). These Fv/Fm values were all within the standard deviation ranges for the various AFT temperatures, and there was no statistical differences between the various indoor display times $(\alpha=0.05)$. Fv/ Fm values for douglas fir confirmed the patterns observed with needle 

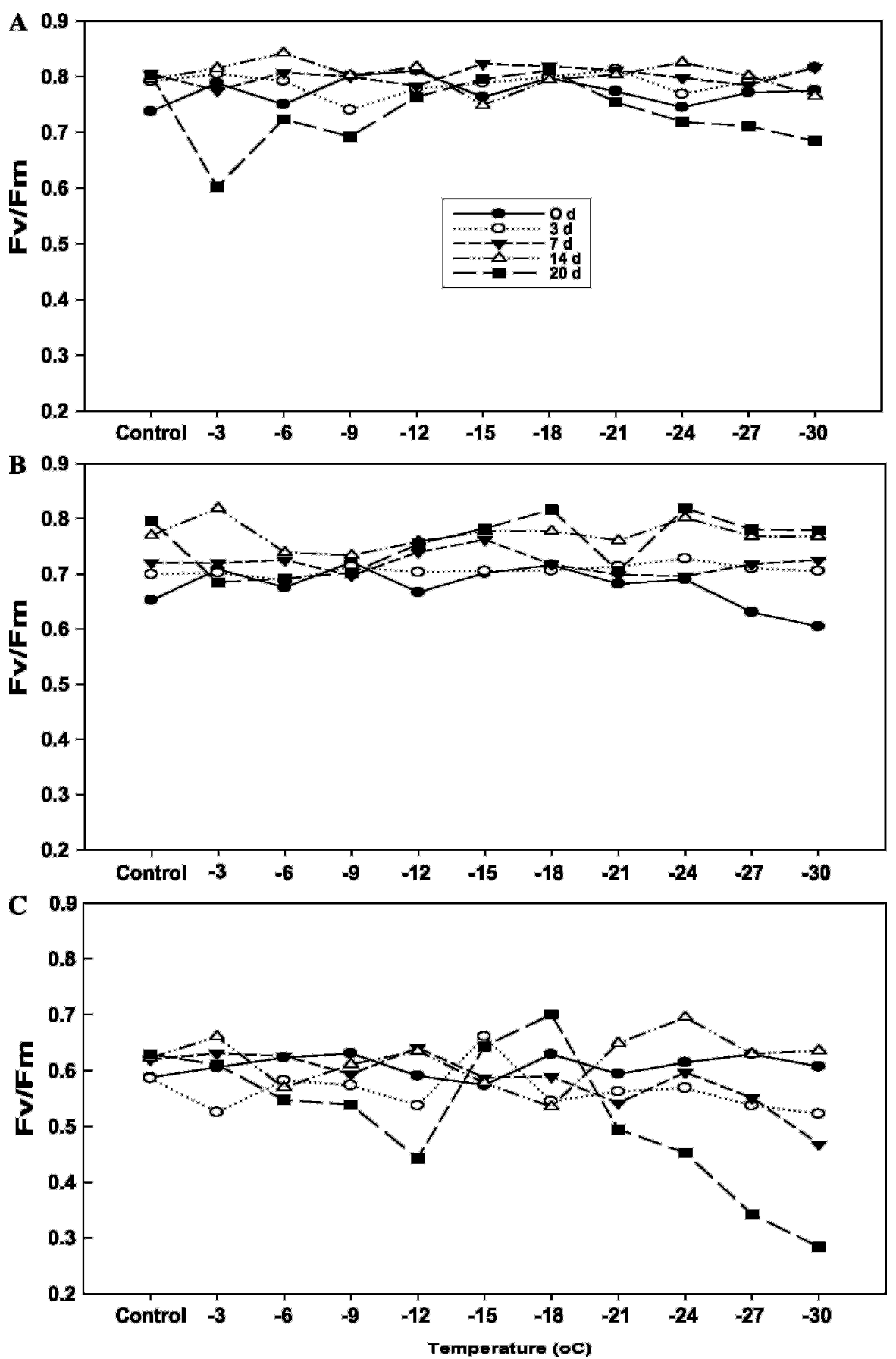

Fig. 3. Effect of indoor exposure $(0,3,7,14$, and $20 \mathrm{~d})$ and subsequent freezing temperature on chlorophyll fluorescence $(\mathrm{Fv} / \mathrm{Fm})$ of $(\mathrm{A})$ black hills spruce, $(\mathrm{B})$ balsam fir, and (C) douglas fir. Fv/Fm values for various indoors exposure treatments were not statistically different (least significant difference at $\alpha=0.05$ ) at all temperatures for balsam fir and black hill spruce, but there were statistical differences between $20 \mathrm{~d}$ and other indoor exposure treatments for douglas fir; (1.8 $\left.\times{ }^{\circ} \mathrm{C}\right)+32={ }^{\circ} \mathrm{F}$.

damage and were generally lower than those recorded for black hills spruce and balsam fir. This lack of effect could be the result of an internal photoprotective mechanism in those species. As expected, the 20-d indoor treatment had the lowest
$\mathrm{Fv} / \mathrm{Fm}$, with values ranging from $0.28( \pm 0.12)$ and $0.70( \pm 0.11)$. The low $\mathrm{Fv} / \mathrm{Fm}$ recorded for douglas fir combined with the yellowish appearance of needles indicate a clear reduction in the photosynthetic ability of the plant.
POST-TREATMENT COLD HARDINESS. When the trees were placed outdoors for cold storage, air temperatures were considerably colder than at the start of the testing in January. The 10-d trees were placed outside on 14 Jan. 2007 and the 20-d trees were placed outside on 24 Jan. 2007. For both treatments, soil temperatures in the pots decreased quickly, reaching temperatures close to ambient (Fig. 2). Temperatures were well below freezing from 25 Jan. until 5 Mar. 2007, and then began to increase slightly. Notably, on 5 and 14 Feb., and 5 Mar. 2007, temperature extremes of $-14,-12$, and $-11.6^{\circ} \mathrm{C}$, respectively were recorded.

Survival and APPEARANCE. The final test of tree response to the two indoor treatments was outdoor survival and appearance. Final visual ratings and survival were conducted on 11 July 2007.

Control trees not subjected to indoor treatments had a $100 \%$ survival rate but varied in visual ratings (Fig. 4). Black hills spruce had the highest visual rating averaging 4.8 and balsam fir also had a high average visual rating of 4.6. The ratings of douglas fir averaged 2.8. douglas fir trees were the most variable in visual ratings. They were the largest in size, with an extensive root system requiring pruning during the potting. The $10-$ and $20-\mathrm{d}$ indoor treatments resulted in $100 \%$ mortality. The high mortality rate was somewhat surprising because minimum temperatures reached following the test were well above the $\mathrm{LT}_{50}$ values (bud mortality) reported for all three species in this study. The lowest temperature recorded during the cold winter storage was $-14^{\circ} \mathrm{C}, 4$ to $7^{\circ} \mathrm{C}$ higher that the $\mathrm{LT}_{50}$ temperatures recorded for 20 -d exposure for all three species (Table $1)$. This result indicates that there are other active physiological and biochemical processes occurring that affect the ability of the plant to recover from the dehardening-rehardeningdehardening cycle caused by the indoor display of dormant trees. Potential factors could include some level of winter dessication, freezing shocks following the move into cold storage due to lack of acclimatation, and hormonal imbalances due to maintenance of some level of photosynthetic activity during cold storage. Another possible explanation to be 


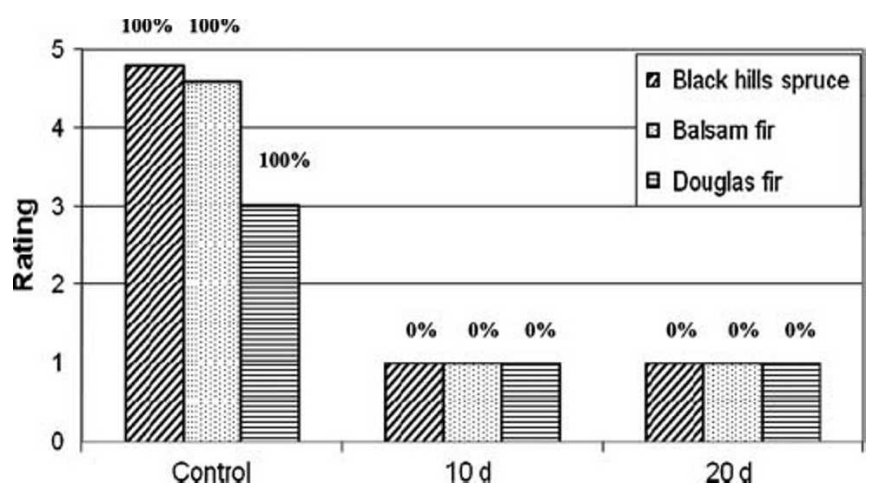

Fig. 4. Visual evaluation and survival potted trees as related to indoor exposure [control (no exposure), 10-d exposure, or 20-d exposure]. Ratings are based on a 1 to 5 scale $(1=$ dead, 5 = excellent $)$. Percentage above the bar indicates survival after transplantation.

considered is a change in root cold hardiness. According to Bigras and Dumais (2005), roots do not develop a high level of dormancy and freeze tolerance as do shoots, and there are still unanswered questions about the dormancy process in perennial plants. Root dormancy is strongly influenced by the soil substrate temperature, and there is a great deal of variability between species. Root deacclimatation during indoor storage followed by cold damage to roots during the cold storage could explain the discrepancy between the AFT results on shoots and plant survival.

\section{Conclusion}

Live Christmas trees have the potential to satisfy a niche market and increase sales compared with selling cut trees alone. The sale of containerized Christmas trees offers the benefit of a higher selling price to the growers. This study investigated the cold hardiness and survivability of three species containerized and handled as live Christmas tree for up to $20 \mathrm{~d}$.

The results obtained indicated that the cold hardiness of tree species was reduced by 5.5 to $10{ }^{\circ} \mathrm{C}$ depending on the species when trees are used indoors at temperatures of 19 to $22{ }^{\circ} \mathrm{C}$ for 10 to $20 \mathrm{~d}$. This reduction in hardiness exposed trees to serious needle and bud winter damage when moved back into cold storage after the holiday. This compromised survival when the trees were transplanted in the spring. Our data also indicated that the pre- and postholiday conditions were very important and affected the dehardening process (preholiday) as well as injuries and mortality (postholiday). However, the most significant result of this study was the $100 \%$ tree mortality obtained after the 10- and 20-d indoor treatments. This result raises serious questions about using dug containerized trees indoors for more than $10 \mathrm{~d}$. Further work investigating the effect of pre- and postindoor conditions on some of the underlying physiological and biochemical processes occurring in trees during the cold-warm-cold cycle created by indoor displays are needed to improve our understanding of the fundamental physiological questions regarding this production system.

\section{Literature cited}

Bannister, P. and G. Neuner. 2001. Frost resistance and the distribution of conifers, p. 3-21. In F.J. Bigras and S.J. Colombo (eds.). Conifers cold hardiness. Kluwer Academic Publishers, Dordrecht, The Netherlands.

Bates, R. 2007. Handling containerized conifers. Great Lakes Christmas Tree J. 2(2):3-9.

Bigras, F.J., A. Ryyppö, A. Lindström, and E. Stattin. 2001. Cold acclimatation and deacclimation of shoot and roots of conifer seedlings, p. 57-88. In F.J. Bigras and S.J. Colombo (eds.). Conifers cold hardiness. Kluwer Academic Publishers, Dordrecht, The Netherlands.

Bigras, F.J. and D. Dumais. 2005. Rootfreezing damage in the containerized nursery: Impact on plantation sites: A review. New For. 30:167-184.

Cleary, B.D., R.D. Greaves, and P.W. Owston. 1978. Seedlings, p. 63-97. In B.D. Cleary, R.D. Greaves, and R.K. Hermann (eds.). Regenerating Oregon's forests. Oregon State Univ. Ext. Serv., Corvallis.

Dungey, R. 2007. Tree talk. 9 Jan. 2007. <http://www.christmastree.org/blog $051130 . \mathrm{cfm}>$.

Glerum, C. 1985. Frost hardiness of coniferous seedlings: Principles and applications, p. 107-123. In: Proc. workshop evaluating seedling quality: Principles, procedures, and predictive abilities of major tests. 16-18 Oct. 1984. Forest Research Laboratory Oregon State University, Corvallis. p. 107-123.

Haworth, K. 1998. A living Christmas tree. Organic Gardening 45:50-51.

Hoogasian, C. 1990. Enjoy it now, plant it later. Florist 24:49-51.

Nix, S. 2006a. Should I buy a "living" Christmas tree. 19 Oct. 2006. <http:// forestry.about.com/library/xmas/blxmsliv. htm>.

Nix, S. 2006b. How to care for a live Christmas tree. 19 Oct. 2006. <http:// forestry.about.com/od/christmastreesl/ ht/living_x_tree.htm>.

Ritchie, G.A. 1984. Assessing seedling quality, p. 243-259. In M.L. Duryea and D. Thomas Landis (eds.). Forest nursery manual: Production of bareroot seedlings. Martinus Nijhoff/Dr W. Junk, Boston, MA.

Russ, K., G.D. Kessler, and B. Polomski. 1999. Living Christmas trees: Home Garden Info. Ctr. Publ. No. 1751. 19 Oct. 2006. <http://hgic.clemson.edu/ factsheets/hgicl75l.htm>.

Schansker, G. and J.J.S. van Rensen. 1999. Performance of active photosystem II centers in photo inhibited pea leaves. Photosynth. Res. 62:175-184.

Wray, P. 2005. Living Christmas trees. 19 Oct. 2006. <http://www.forestry.iastate. edu/topics/community_forest/licechris. htm>. 